\title{
RECOMBINATION OF THE CHARACTER IN THE STORY BY V. PETROV «AN ENAMALLED BOWL»
}

\author{
Kravchenko Valentina \\ Candidate of Philological Sciences, Associate Professor \\ ORCIDID 0000-0001-6318-8758 \\ Zaporizhzhia National University \\ 66, Zhukovskoho Str., Zaporizhzhia, 69063, Ukraine \\ kravchenko_v_o@i.ua
}

The investigation article is carried out on the basis of the story "An Enamelled Bowl» by V. Petrova. It traces a chronotopic model, which is archetypal for V. Petrov's works: human existence in times of ideological change becomes catastrophic for it, because it is «reprogrammed»; the worldview, psychology and morality are comprehended, the social values of the artist are defined in order to realize the spiritual and aesthetic essence of the character of the work; the author's artistic mechanisms of their embodiment are revealed; the development of the conflict is traced to show the confrontation of different ideas.

In study brought the focus is on the fact that the inner freedom of uniqueness is the basis of existential morality - people place confidence in myself, have a guard in oneself, frankness with oneself is the opposition of world disharmony.

The system of figurative-expressive means and techniques are analyzed, in particular, the landscape, which enhances the tragedy of the situation, dialogues that dramatize the action, the symbolism of color, descriptions of the interior, which help to create a psychological portrait of the character.

In the work emphasize a point that the idea of human life, asserted by V. Petrov, gives rise to another - the idea of self-denial in the name of work for the benefit of mankind.

The writer's understanding of rigidity, as a statement of the inviolability of power, clearly correlates with the aesthetic pursuits of V. Petrov, consistent with the new aesthetic and philosophical views in Europe.

Key words: recombination, individual, crisis of values, chronotope, landscape, picturesque, absurdity of the being, existence, autobiographical character.

\section{РЕКОМБІНАЦІЯ ОСОБИСТОСТІ В ОПОВІДАННІ «ЕМАЛЬОВАНА МИСКА» В. ПЕТРОВА}

\section{Кравченко Валентина}

кандидат філологічних наук, доцент, професор кафедри української літератури

ORCIDID 0000-0001-6318-8758

Запорізький національний університет

вул. Жуковського, 66, м. Запоріжжя, 69063, Україна

kravchenko_v_o@i.ua

Дослідження здійснено на основі оповідання В. Петрова «Емальована миска». У ньому простежено хронотопну модель, яка для творів В. Петрова є архетипною: буття людини в часи ідеологічних змін стає для неї катастрофічним, адже ї «перепрограмовують»; осмислено світовідчуття, психологію та мораль, означено суспільно иіннісні орієнтири мития 3 метою усвідомлення духовно-естетичної сутності персонажа твору; розкрито власне авторські художні механізми їхнього

(C) Kravchenko V., 2020 
втілення; простежено розгортання конфлікту, щзоб показати протиборство виразників різних ідей.

Наголошено, щзо внутрішня свобода особистості є основою екзистенційної моралі - людина повинна покладатися на себе, мати опору в собі, а відвертість із собою постає як своєрідне протиставлення світовій дисгармонії.

Проаналізовано систему зображально-виражальних засобів і прийомів, зокрема пейзаж, який підсилює трагізм ситуаиії, діалоги, щзо драматизують дію, символіка кольору, описи інтер'єру, які допомагають створити психологічний портрет персонажа.

Наголошено, ш⿻ стверджена В. Петровим ідея життя людини породжує іншу - ідею самозречення в ім'я праці на благо людства.

Письменнищьке розуміння застиглості, як ствердження непорушності влади, чітко корелює з естетичними пошуками В. Петрова, суголосне новим естетичним філософським поглядам у європі.

Ключові слова: рекомбінація, особистість, криза иінностей, часопростір, пейзаж, колористика, абсурдність буття, автобіографізм.

\section{Вступ}

Життя і творчість В. Петрова магнетизують і сьогодні увагу дослідників. Йому присвятили розвідки В. Брюховецький, I. Бурлакова, М. Гірняк, С. Ленська, Н. Мариненко, Н. Мішеніна, О. Наумова, С. Павличко та ін.

І. Бурлакова обгрунтувала тезу про «неокласицизм» В. Петрова, «шостого 3 грона п’ятірного», на матеріалі оповідання «Приборканий гайдамака», написаного в мурівський період творчості. На прояви «неокласичної» естетики у творі вказують історіософська парадигма, інтертекстуальність, культурологічний дискурс письма, особливості архітектоніки.

Н. Мішеніна проаналізувала прозу В. Петрова в розрізі інтертекстуальності. Стверджено, що тема невідповідності загальної та індивідуальної свідомості проходить через його цикли «На засланні», «1921 рік», через біографічні нариси про Ван Гога, Франсуа Війона, оповідання «Емальована миска», «Приборканий гайдамака», роман «Без грунту». Поділяємо думку дослідниці, що «катастрофічним для людської свідомості стає буття в час зміни ідеології, витворення нових стандартів і кліше. Для текстів Петрова архетипною стає така хронотопна модель: катастрофічним зламам часу відповідає особливий герой. Він поєднує норми життя, мораль, стереотипи двох епох, або заперечує одні на користь інших» (Мішеніна, 2002: 32). Отже, тема доби для письменника була актуальною.

С. Ленська 3'ясувала функціональні особливості, семантичну місткість біблійного компоненту, образів і мотивів, проявлення символічного змісту прототексту в оповіданнях «Апостоли» В. Петрова і «Сміх Іскаріота» В. Русальського (Ленська, 2014).

Однак оповідання В. Петрова ще потребують поглибленого аналізу. Мета нашого дослідження - осмислити ідею самоствердження особистості, враженої суспільною жорстокістю в оповіданні «Емальована миска». Мета передбачає вирішення завдань: охарактеризувати філософсько-естетичні погляди митця та проаналізувати систему зображально-виражальних засобів і прийомів у творі.

\section{Матеріали та методи дослідження}

Об’єктом нашої розвідки стало оповідання «Емальована миска» В. Петрова, яке приваблює вже назвою атрибута повсякденного людського життя - емальована миска. Назва твору корелює зі змістом, в основі якого - нівеляція всього людського.

В оповіданні В. Петров підняв важливі проблеми: існування митця в усій його повноті, сутність людини, ऑiі внутрішній світ, протиріччя суспільного буття, свобода/несвобода особистості та іiі відповідальність, людина як об’єкт маніпуляцій 
влади, суспільна залежність, позбавлення індивіда всього людського в умовах насильства, «виховання» його засобами тоталітарного режиму тощо.

У роботі реалізовано загальні методи наукового дослідження (аналіз, синтез, опис, інтерпретація) і власне літературознавчі, 3-поміж яких пріоритетним став культурно-історичний, що посприяв розкриттю особливостей оповідання у зв'язку 3 історичними та культурними обставинами. Аналітико-описовий метод дозволив дати структурно-змістову характеристику твору.

\section{Обговорення}

В. Брюховецький називав В. Петрова «гуманітарієм». Його розмірковування про письменника і його творчість - високодумні: «Головне те, що письменник написав. Проте вперто виринає мульке питання: ми шукаємо в художньому творі те, про що пише автор, чи те, що ми хочемо побачити?» (Брюховецький). Тому, беручи до уваги термін 3 біології «рекомбінація», сутність якої, у нашому випадку, «перепрограмування» людини, чого насправді не може бути, констатуватимемо майстерність В. Петрова відповідати на складні питання: Що є людина? Чого варта людина? У чому сила влади? Як змінює влада долю людини?

Щоб усвідомити духовно-естетичну сутність персонажа твору, важливо осмислити світовідчуття автора, зрозуміти його психологію та мораль, означити його та суспільні ціннісні орієнтири. Озброївшись твердженням Н. Зборовської про те, що «внутрішне, душевно-духовне, інтелектуально-емоційне, психологічне життя особистості» $\epsilon$ «найістотнішим чинником життєтворчості (життя-як-творчості)» (Зборовська, 2006: 9], наблизимось до енергетичної сутності письменника, осмислимо процес руху власне авторських художніх механізмів.

В. Петрова приваблювала сильна харизматична особистість, зі своєю життєвою історією, неординарними вчинками і діями, якою він був і сам. Поділяємо думку В. Брюховецького, що В. Петрова «..цікавили не факти самі по собі, а саме їхній взаємозв'язок. Подібне бачимо й у деяких художніх творах [...] це своєрідні «рімейки» за фактажем із письма інших авторів, іноді майже тотожні текстуально, але в концептуальному вираженні художньої ідеї - проза цілком оригінальна»; «В. Петров не боїться оголювати деякі із засобів «художнього плетення» своїх творів як літературознавець»; «В. Петрову імпонує в літературі пріоритет думки, навіть не так просто думки, як боротьби думок, змагання ідей, коментування цих змагань» (Брюховецький, 2013: 40). Отож, конфлікт, як правило, і розгортається в боротьбі цих домінант. Ним, як художником, рухають мотиваційні загадки. У більшості його художніх творів спостерігаємо гру, протиборство виразників різних ідей, що характеризує сюжет із витонченою інтелектуальною напругою.

Розмірковування історіософа про смисл буття закорінені у ХX ст.: «Над усім панує епоха. Функція людини за однієї доби одна, а за іншої - інша. У зміні діб втрачає вагу сталість особи. Жаден з нас не має власної біографії, бо його біографія належить відтинкам епох, які круто відрізняються один від одного [...] Зміну діб сприйнято як особисте переживання. Ïї усвідомлено на прикладі власної долі. Трагедія останніх поколінь полягає в тому, що вони живуть уривками уявлень різних діб, тоді як вони належать новій, іншій, якої вони ще не уявляють собі» (Павличко, 1999: 282).

\section{Результати дослідження}

Залежність В. Петрова від часу, обставин, оточення живились синтезом взаємопогоджених філософії життя і філософії творчості. Сповідувані ним гуманістичні ідеї втілювалися в оригінальну тематику й огорталися незвичайними сюжетними конструкціями, а присутність автора у творі позначалася блискучим стилем і афористичною думкою, що й дало право називати його «паном форми», майстром інтелектуального письма.

Криза гуманістичних цінностей у суспільстві породила специфічний тип персонажа у виняткових побутових умовах в оповіданні «Емальована миска» 
В. Петрова. Йдеться про високий ідеалізм митця-модерніста, котрий поставив свою творчість вище за всі людські цінності. Це герой-маргінал, що не може співіснувати 3 дійсністю. Він намагається пояснити це можновладцям, щоб перервати слабке животіння й бути корисним суспільству. Автор скрупульозно аналізує стан людини, котра переживає крах узвичаєних цінностей і не може адаптуватись до нового часопростору.

В оповіданні «Емальована миска» чітко сформульована ідея: митець - заручник влади. У фразі «Я обстоював права кожної людини...», вкладеній в уста головного персонажа, - формула життя й самого автора. Обстоюючи проблеми моралі, етики, психології, В. Петров показує шлях до гармонії в душі людини та гармонії людини і суспільства. Чесність із собою, право власного вибору й відповідальність за нього - це те, до чого прагне головний персонаж оповідання. Внутрішня свобода особистості $є$ основою екзистенційної моралі: людина повинна покладатися на себе, мати опору в собі, а відвертість із собою постає як логічний наслідок визнання людини вільною, як своєрідне протиставлення світовій дисгармонії.

В. Петров, наповнюючи оповідання персонажами, утілив у них власні думки, що стосуються особистості, іiі автентичності, місця в універсумі. Це людина, екзистенцію якої можна визначити як напівбуття/небуття в замкнутому просторі психіатричної лікарні. Учений відчужений від усього світу.

Жахливу безнадійність становища людини, оголошеної хворою, В. Петров змалював уже на початку твору. Превалювання сірого кольору, як символу безпросвітності («сірий халат», «сірозелена далечінь»), принизливо-убоге стандартне смугасте вбрання пацієнтів психіатричної лікарні та його зовнішність, з авторським акцентуванням на безпомічності й незграбності, а ще й порівняння зі сліпими утверджує абсолютну безвихідь. Цьому слугують зображально-виражальні засоби, зокрема пейзаж, який підсилює трагізм ситуації: здавалося 6 , усе свідчить про радість життя («відкритий горбок», «жовта доріжка», «темно-зелені кущі ліщини»), але опис доріжки, яка, «ніби одрізана, заломлювалась», простору, «перерізаного вузькою щілиною глибокого яру», заперечує це.

Убивча констатація приреченості людини досягнута змалюванням глибокої безодні між представниками двох таборів: «...один володіє необмеженим авторитетом, правом єдиного й виключного присуду, цілитель, геній і маг, могутній і безумовний владар $[. .$.$] всемогутніший в своїй умовній величі за Чінгіс-хана», інший - «...один 3$ тих, що позбавлені власного ім'я й всіх життєвих відрізнень», «...ніщо, підлеглий, нівельований і знищений» (Петров, 2006: 895).

Світосприйняття й виклад подій від першої особи інтимізує наратив. Опис зовнішності нормальної, але вже надломленої людини в закритому часопросторі («спокійний, лагідний, врівноважений, без тієї розхристаної збуджености, яка властива психічним хворим. Високий на зріст, стрункий, з синіми, немов замріяними, очима i ясним відкритим чолом») (Петров, 2006: 896) потверджує міць владущої системи, яка розчавлює людину. Існування людини в абсурдному світі потвор, якими їх змусила стати влада, відправивши в закритий простір (психіатрична лікарня), неможливе. Серед «...кретинів, паралізованих, серед фантастичних виродків і недоносків 3 одвислими й слинявими устами, серед маніяків зі спиненим і відсутнім поглядом», «...нелюдів, напівлюдей, тварин, які вже пізнали, що таке людський гріх і людський злочин» (Петров, 2006: 896), куди відправили здорову людину, неугодну владі, вона перетворилася на худобину. А тому ідея ствердження життя, що завжди пов'язана 3 буттям людини та ii творчістю, справжнє повноцінне життя, закладене природою, закодоване генетично, а не животіння, гіпертрофується, втрачає первісну суть, видозмінюється, рекомбінується під впливом зовнішніх обставин. Людина-митець все ж не заспокоюється, обстоює власне право вважатися здоровою, звільнитись, і в цій ситуації безправності вона піднімається на найвищий щабель самозречення, нехтуючи елементарними побутовими умовами, прийнявши правила життя упослідженої 
людини. Отож, ідея життя людини породжує іншу - ідею самозречення в ім'я праці на благо людства.

Автор подав портрет-ствердження нормальності людини в ненормальному середовищі: «...без тієї німої й темної пригнічености, що важкими зморшками, як рубцями ран, карбує обличчя»; «...він один справляв враження людини. Ті несли на собі клеймо кари, цей же був чистий. Він становив виняток» (Петров, 2006: 896). Боязкість, нерішучість, ніяковість, сором'язливість («на його обличчі виступив ніжний, як у дівчини, рум'янець» (Петров, 2006: 896), - констатовані автором риси людиниінтелігента, що розкривають сутність його характеру. В. Петров-психолог вправно змалював психологічний портрет персонажа: «делікатна боязкість», «...мрійлива нерішучість, заглиблена в собі відсутність», «спазма кривила йому уста» (Петров, 2006: 896), констатуючи вихованість, яка в умовах, не придатних для життя, як виявилося, теж є ознакою божевілля. «Хворий», як добрий знавець психології, добре розуміє ситуацію, називає себе «...схемою з відповідей на анкетні питання, наперед передбачений висновок» (Петров, 2006: 896-897). Але свідомий орієнтир митця - бути корисним людству: «Мені байдужа моя власна життєва доля...» (Петров, 2006: 897).

Будь-який митець має бути професіоналом. Лікар із професійною допитливістю намагається зрозуміти «хворого»: «Я зважував кожну його думку, я стежив за кожною його фразою, за виразом обличчя, за хмаринкою, що мимохіть з'являлася на його обличчі» (Петров, 2006: 897). Точність і влучність фраз характеризують лікаря: «3 пожадливістю мисливця, що стежить сліди своєї здобичі, з жорстокістю слідчого, що не знає вагань» (Петров, 2006: 897).

Всемогутня система влади настільки пригнічує таку людину, і в силу іiі скромності розвиває в ній комплекс неповноцінності, що в цій безвиході така особистість, намагаючись подолати перешкоди (вирватись на волю), ствердитись, виглядає хворою. Філософу поталанило, що його лікар «...не належав до числа тих лікарів, які в кожній людині бачили хворого. Серед своїх колег», - як лікар сам зізнавався, - «...я був майже єдиний, який не поділяв їх манії трактувати здорових як хворих» (Петров, 2006: 898). I «хворий» філософ отримав надію на визволення.

Довіра пацієнта лікарю - це його розповідь про свою незакінчену розвідку про Гассенді 3 філософії 17 ст., страждання від відсутності умов займатися улюбленою справою, наукою. Лікар зрозумів хворого: він - здорова розумна людина, ерудит, який намагається ствердити право бути людиною. Зрозуміло, що думки оповідача й головного персонажа зливаються воєдино: «Шопенгауер [...] сказав, що суспільство $є$ не сума осіб, що існують, а сукупність мислителів, що існували» (Петров, 2006: 900).

Важливість справдження надії, що зажевріла в душі митця-в’язня, підсилюється змалюванням душевного стану: похилена голова, плечі, пригнічені сумом, горе, що неможливо висловити, і пейзажем. А логічно наголошені кольори, гра сіро-зеленого та біло-синього, продукують думку про щасливий кінець: «За яром сріблився сірозелений степ. Біло-синя димчаста височінь неба підносилася мерехтливим сяйвом» (Петров, 2006: 900).

Один світ, а дві долі: «хворий» чекає, а лікар, із «враженою чеснотливістю сумління», намагається знайти підтвердження його «людинності». В описі бібліотеки, де лікар прочитав окремі блискуче написані «хворим» розділи 3 великої праці, що «...свідчили про ясний розум і про думку, чітку й величну, сповнену уявою грандіозности» (Петров, 2006: 900), переважають світлі кольори («ясний абажур», «білі сторінки книжки», «великі (курсив наш - В.К.) вікна»). Білий колір символізує чистоту, у цьому випадку - правду «хворого». Отож, насправді митець-філософ не хворий, його відправили до божевільні, оголосивши таким. Лікар розуміє: це поет, філософ, мрійник, який відкривав нові шляхи людству.

Автор оповідання устами головного персонажа констатує суть життя: «Людству, щоб існувати й не загинути, бракує доброти й зрозуміння», що нагадує загальновідоме Шевченкове «А всім нам вкупі на землі єдиномисліє пошли і братолюбіє подай»; «історія $[. .$.$] - проекція в майбутнє, проект майбутнього. Це той схематичний плян, що$ 
його викреслило минуле, щоб ми й наші нащадки збудували за ним будівлю» (Петров, 2006: 902).

«Хворий», митець, був щасливий, що його зрозуміли. Психологія щасливої людини вияскравлюється письменником у його діях: «Він просяяв. Він повірив в можливість звільнення. Його обличчя просвітліло ясною радістю» (Петров, 2006: 901); «...він судорожно вхопився за рукав мого піджака» (Петров, 2006: 902); «в захопленні, пожадливо, він зазирав мені в вічі» (Петров, 2006: 902).

Образ старшого лікаря виписано як представника влади в комічно-іронічному тоні: «Широкий і громіздкий, він заповнював собою крісло. Здавалось, тільки поруччя крісла, охоплюючи його ззовні, обмежували безмірність його тіла» (Петров, 2006: 902). Цей образ $є$ уособленням безмірної влади людини-чиновника, надлюдини. Іронічний тон, насмішкуватий і поблажливий, у розмовах із персоналом, лікарями і хворими свідчить про вседозволеність, міць влади, а ще увага автора до деталі, яка $\epsilon$ засобом розкодування підтексту («був ще ранок, а від нього вже тхнуло горілкою», «хронічний алкоголік»), говорить про ії руйнацію, ураженість вірусом бездушності.

Письменник поглиблює сутність старшого лікаря 3 тим, що та надія на визволення, яка ледь жевріла у митця, ніколи не реалізується: «Він звів на мене свій важкий нерухомий зір $[\ldots]$ дивився $[\ldots]$ червоними склеротичними очима, напівсхованими під зморшками важких повік. Він астматично дихав. Я бачив перед собою його короткий гострий, як клюв хижака, ніс і тверде підборіддя на його широкому темному обличчі» (Петров, 2006: 903). Старший лікар - це та суспільна болячка, яка розрослася на повну силу, користується необмеженими правами: «Він був цинік і скептик. Він любив жінок, горілку й книжки, оправлені в гарні палітурки [...] не вірив ні в що [...] не терпів заперечень» (Петров, 2006: 903-904). Таким же $\epsilon$ й інший представник влади, безграмотний райінспектор наросвіти.

Отже, зображально-виражальні засоби В. Петров підпорядкував глибокому проникненню в душевні муки творчої людини, яка потерпає від невігластва. Діалог між двома лікарями про приреченого - це битва між представниками одного табору, але різних принципів: один із них - сповідує правду, інший - керівник, породжений системою. На довід лікаря, що йдеться про одну конкретну людину і про злочин щодо цієї здорової людини, старший лікар байдуже відповів: «Що таке злочин...? Ми їх робимо щодня тисячі!» (Петров, 2006: 903). І вдруге логічно наголошене письменником «...зірке хижацьке око яструба» (Петров, 2006: 904) не залишає надії на торжество справедливості. Більше: всезагальне визнання старшого лікаря, його досвід і точність діагнозів ні в кого не викликали сумнівів, тобто владуща система працює за чітко встановленими правилами. I свою думку старший лікар насаджує підлеглому. Відбувається рекомбінація думок лікаря щодо пацієнта. Що ж є ознакою хвороби цієї «нехворої» людини? Банально просто: згадка про емальовану миску!?

Але лікар божевільні ще не втратив людського ставлення до людини. Він чинить опір системі, представником якої $є$ й сам, і старший лікар. В історії життя-хвороби пацієнта, яку він переглянув, відбилося звичайне життя людини: народження, навчання, аспірантура. Але у стенографії дискусії в ІЧП з приводу його доповіді «Етика Гассенді на тлі механістичної філософії 17 століття» лікар знайшов звинувачення у «...протягуванні ідеалістичної контрабанди, в фідеїзмі, попівстві, антимарксистських ухилах, в гегеліянстві, плехановщині, деборінщині. Йому закидають зв'язки 3 ворогами народу. Брак пильності 3 його боку. Його праці оголошені вилазками клясового ворога» (Петров, 2006: 905-906). Це - причина «хвороби», вирок, який знищить людину не фізично, а морально. В. Петров констатував цей факт нанизуванням простих речень, які породжують страх: «Сакральне слово виголошено. Катастрофа сталася. Людина зійшла на ешафот. Трикутний шматок важкої криці з холодним блиском упав вниз. Голова одрубана ножем гільйотини, покотилася до кошика. Візок з трупами прогуркотів по бруківці» (Петров, 2006: 906); «Його немає. [...] Тепер він ніщо» (Петров, 2006: 907). Загалом людина народжена для життя і творчої праці, але система влади перепрограмовує 
неугодних їй людей, всіма засобами підпорядковуючи їхню волю: «Людини більше немає, є труп, не-людина, тінь, двійник людини, буття тіні, ілюзія існування [...] буття заблуканого привиду» (Петров, 2006: 906). Життя ії - це картина суцільних жахів, яку вправно змодельовано: «Мрець живе неживим життям вигаданої істоти. Він живе в світі, реальність якого умовна» (Петров, 2006: 906). Поодинокі прості, короткі, риторичні речення додають трагізму («Та й чи $\epsilon$ він насправді?»).

Автор умотивував відчай людини-лікаря, який глибоко проник у трагедію особистості, чому підпорядкував і опис його зовнішності («заплющені очі»), і вдале порівняння зі сліпими старцями, що є ствердженням безнадійності. Блакитний колір тютюнового диму, як символ надії, ніби має врятувати ситуацію, але він безслідно тане у повітрі, що й передбачає трагічну розв'язку. Лікар адекватно сприймає сутність філософа, свідомість якого отруєна почуттям власної безневинності, і розуміє, що основою руйнації його психіки стала звичка митця мислити логічно.

Розв'язка сюжету готується повільно. Автор ввів пейзаж, який драматизує дію, стверджуючи можливість творчого життя людини («...широка галявина 3 сіном, що солодкаво в’яне в копицях, білі стіни головного будинка, за зелом дерев бані церкви 3 божевільно-урочистими фресками Врубеля» (Петров, 2006: 909). Довіра пацієнта до лікаря, що виказувалася «тихими ясними очима», розбивається, хоча лікар і бачить не хвору людину, а людину світлу, з «високим ясним чолом філософа». Важкий діалог між лікарем і хворим (розмова двох здорових людей!) - діалог «системи» й підлеглого.

Гра 3 кольорами у розв'язці, як і в зав'язці оповідання, що є обрамленням, витвережує, навертає до реального світу: білий колір («білий халат лікаря»), як символ чистоти, трансформується, стверджуючи не чистоту помислів, а правоту провладного, «системи», а сірий і рожевий («сірий з рожевими смужками халат хворого») - кольори приниженого. «Хворий» для лікаря лише «...порядкове число в книзі для записів, ланка доктрини, об'єкт для перевірки наслідків лікування інсуліном» (Петров, 2006: 909).

Символічним $\epsilon$ й те, що протиборство двох таборів автор розкрив через взаємини двох безіменних - «Я» і «Він», у такий спосіб типізуючи обставини. Зіткнулися два світи, два погляди на світ. В уста «хворого» автор уклав нищівну характеристику пануючої системи влади: «...вони здібні без жадних підстав для того обвинувачувати цілком безневинну людину в ніколи не зроблених злочинах і вимагають в тому зізнань. Світ збожеволів...» (Петров, 2006: 909).

Сповідь невинного викликала душевне збурення в лікаря: від безсилля йому «хотілось плакати». Але останній довід визнання здорової людини хворою констатація «хворим» факту, що він «їсть суп з емальованої зеленої миски» разом 3 усіма, став лише доводом його неіснуючої хвороби, шизофренії, яку запопадливо поставив йому старший лікар. Розв'язка твору - торжество владущої системи, про що свідчить ще один опис ï яскравого представника, старшого лікаря: «Від нього пахло важким горілчаним перегаром. Він астматично дихав. Я бачив його червоні очі, напівсховані під зморшками тяжких повік, короткий гострий ніс степового хижака й тверде уперте підборіддя» (Петров, 2006: 910-911).

В. Петров передав трагедію людини, розчавлену владою: «Постать людини 3 понурою головою в сірому халаті чітко викреслювалась на тлі сіро-зеленого неба» (Петров, 2006: 911). Щоразу акцентуючи на сірому кольорі (таким буде подальше життя особистості в умовах, не придатних для життя), автор додав зеленого, як ствердження продовження життя. Зворушливості у сприйнятті трагедії особистості та iї безсилості щодо тоталітарної системи, додав останній штрих-пейзаж: «Вузькохвоста пташка 3 тонкими ніжками, дрібно підстрибуючи, пробігла по стежці. Солодкий аромат свіжого сіна млосно застиг у нерухомому повітрі» (Петров, 2006: 911). Застиглість - ствердження непорушності влади. Такий кут письменницького художнього викладу досить чітко корелює 3 естетичними пошуками В. Петрова повоєнного періоду й суголосний тим новим естетичним і філософським поглядам у Європі, що в подальшому набудуть свого повноцінного логічного вигляду в працях 
М. Фуко, зокрема біополітичні проблеми здоров’я/хвороби, психічної норми та витіснених ідентичностей.

\section{Висновки та перспективи}

Отже, в оповіданні «Емальована миска» В. Петрова відбилася політика середини XX століття, коли відбувалась масштабна війна між системами. Атмосфера твору позначена настроями абсурдності буття. Прагнення головного героя зберегти власне «я» - неможливе, чому автор підпорядкував традиційні зображально-виражальні засоби: портретні характеристики, пейзаж, який підсилює трагізм ситуації, діалоги, що драматизують дію, символіку кольору, описи інтер'єру, які допомагають створити психологічний портрет персонажа.

В. Петров глибоко проаналізував справжній стан речей - причини приреченості ученого чоловіка XX ст. Беззаперечно, оповідання позначене автобіографізмом. Автор утвердив думку, що єдино можливий шлях до реалій буття людини та суспільного процвітання - розвиток духовності.

Оповідання $\epsilon$ тим своєрідним простором, у якому все життя людини підпорядковано принципам пануючої системи, які створюють нову художню реальність. Розмірковування В. Петрова про руйнування звичного світу людини, приреченість особистості в обставинах тоталітарної системи роблять оповідання «Емальована миска» В. Петрова актуальним у контексті доби.

Вважаємо, що майбутні дослідження розширюватимуть горизонти для детального розгляду прийомів зображення дійсності в інших текстах автора.

\section{СПИСОК ВИКОРИСТАНИХ ДЖЕРЕЛ}

Агеєва, 2006 - Агеєва В. Поетика парадокса. Інтелектуальна проза Віктора Петрова Домонтовича: Монографія. Київ: Факт, 2006. 432 с.

Брюховецький, 2019 - Брюховецький B. «Фокус долі». URL : http://shron1.chtyvo.org.ua/Briukho vetskyi Viacheslav/Viktor_Petrov_Fokus_doli.pdf (дата звернення : 10.11.2019).

Брюховецький, 2013 - Брюховецький В. Віктор Петров. Розвідки : у 3 т. Т. 1. Київ : Темпора, 2013. 590 с.

Бурлакова, 2010 - Бурлакова I. «Ми у руці тримаєм тільки зерна...» : новелістика на тлі маніфестацій МУРу : монографія. Київ : Якубець А. В. 2010. 359 с.

Гірняк, 2007 - Гірняк М. Жанрова парадигма прози В. Петрова-Домонтовича в контексті проблеми авторської само артикуляції. Studia methodologica : теорія літератури. Компаративістика. Україністика: зб. наук. праць 3 нагоди 70-річчя проф. Р. Гром’яка. Тернопіль : Підручники і посібники, 2007. Вип. 19. С. 226-236.

Зборовська, 2006 - Зборовська Н. Код української літератури : проект психоісторії новітньої української літератури : монографія. Київ : Академвидав, 2006. $504 \mathrm{c}$.

Ленська, 2014 - Ленська С. Функції біблійного компоненту в структурі оповідання В. Домонтовича «Апостоли» і новели В. Русальського «Сміх Іскаріота». Наукові записки ХНПУ ім. Г. С. Сковороди, 2014. Вип. 2(78). Ч. 1. С. 59-72.

Мішеніна, 2002 - Мішеніна $H$. Історіософський мотив зміни епох як модель внутрішнього інтертексту (проза Віктора-Петрова-Домонтовича). Слово і час. 2002. № 11. С. 26-32.

Наумова, 2013 - Наумова О. Ігровий чинник романістики В. Петрова-Домонтовича : автореф. дис. ... канд. філол. наук : 10.01.01. Харків, 2013. 21 с.

Павличко, 1999 - Павличко С. Дискурс модернізму українській літературі : монографія. Київ : Либідь, 1999. 447 с.

Петров, 2006 - Петров В. Емальована миска. Українська мала проза XX століття : антологія. Київ : Факт, 2006. С. 895-911. 


\section{REFERENCES}

Ageyeva, 2006 - Ageyeva V. (2006). Poetyka paradoksa. Intertekstualna proza Viktora Petrova-Domontovycha [Poetics of Paradox : Intertextual prose of Victor PetrovDomontovych]. 432 p. [in Ukrainian]

Briukhovetskyi, 2019 - Briukhovetskyi V. (2013). «Focus doli» [The Focus of Fate]. URL : http://shron1.chtyvo.org.ua/Briukhovetskyi_Viacheslav/Viktor_Petrov_Fokus_d oli. pdf (accessed : 10.11.2019). [in Ukrainian]

Briukhovetsyi, 2013 - Briukhovetsyi V. (2013). Viktor Petrov. Rozvidky : u 3 t. T. 1. [Victor Petrov. Explorations: in 3 volumes]. Vol. 1. 590 p. [in Ukrainian]

Burlakova, 2010 - Burlakova I. (2010). «My u rutsi trymaiem tilky zernia ...» : novelistyka na tli manifestatsii MURu. [«We only hold grains in our hands ...»: short stories against the background of the manifestations of the AUM]. 359 p. [in Ukrainian]

Hirnyak, 2007 - Hirnyak M. (2007). Zanrova paradyhma prozy V. Petrova-Domontovycha v konteksti problem avtorskoi samoartykuliatsii. [Genre paradigm of prose of V. Petrov-Domontovych in the context of the problem of author's selfarticulation]. Studia methodologica: Theory of literature. Comparativistics. Ukrainian Studies. Iss. 19, pp. 226-236. [in Ukrainian]

Zborovska, 2006 - Zborovska N. (2006). Kod ukrainskoi literatury : proekt psykhoistorii novitnoi ukrainskoi literatury. [The Code of Ukrainian literature : project of psychohistory of modern Ukrainian literature]. 504 p. [in Ukrainian]

Lenska, 2014 - Lenska S. (2014). Funktsii bibliinoho komponentu v strukturi opovidannia V. Domontovycha «Apostoly» i novely V. Rusalskoho «Smikh Iskariota». [Functions of Biblical component in the structure of the short story by V. Domontovych : «The Apostles» and in the novella by V. Rusalskiy «The Laughter of Iscariot»]. Scientific Proceedings of the KhNPU of G. Scovorodu. Iss. 2 (78). P. 1., pp. 59-72. [in Ukrainian]

Mishenina, 2002 - Mishenina N. (2002). Istoriosofskyi motyv zminy epokh yak model vnutrishnoho intertekstu (proza Victora Petrova-Domontovycha). [Historiosophical motive of change of epochs as a model of internal intertext (prose of Victor Petrov-Domontovych).]. Word and Time. Nr. 11, pp. 26-32. [in Ukrainian]

Naumova, 2013 - Naumova O. (2013). Ihrovyi chynnyk romanistyky V. PetrovDomontovych. [The playing factor of novels of V. Petrov-Domontovuch]. $21 \mathrm{p}$ [in Ukrainian]

Pavlychko, 1999 - Pavlychko S. (1999). Dyskurs modernizmu v ukrainskii literaturi. [The Discourse of Modernism in Ukrainian literature]. 447 p. [in Ukrainian]

Petrov, 2006 - Petrov V. (2006). Emalovana myska. Ukrainska proza XX stolittia. [En Enamelled Bowl. Ukrainian prose of the XXth century]. P. 895-911. [in Ukrainian]

Received: 05 August, 2020 
